\title{
Linoleic and $\alpha$-linolenic fatty acid consumption over three generations exert cumulative regulation of hepatic expression of genes related to lipid metabolism
}

\author{
Carolina B. Jacometo • Eduardo Schmitt $\cdot$ Luiz F. M. Pfeifer • Augusto Schneider • \\ Francielle Bado $\cdot$ Fernanda T. da Rosa $\cdot$ Simone Halfen - Francisco A. B. Del Pino • \\ Juan J. Loor · Marcio N. Corrêa $\cdot$ Nelson J. L. Dionello
}

Received: 22 January 2014/ Accepted: 5 May 2014/Published online: 20 May 2014

(C) Springer-Verlag Berlin Heidelberg 2014

\begin{abstract}
The essential fatty acids, omega-3 and omega6 , consumed during pregnancy can benefit maternal and offspring health. For instance, they could activate a network of genes related to the nuclear receptor peroxisome proliferator-activated receptor $\alpha$ (Ppara) and sterol regulatory element binding transcription factor 1 (Srebf1), which play a role in fatty acid oxidation and lipogenesis. The present study aimed to investigate the effects of diets with different omega-3/omega-6 ratio consumed over three generations on blood biochemical parameters and hepatic expression of Ppara- and Srebf1-related genes. During three consecutive generations adult Wistar rats were evaluated in the postpartum period (21 days after parturition). Regardless of prenatal dietary omega-3/omega-6 ratio, an upregulation in liver tissue was observed for Rxra, Lxra and Srebf1 and a downregulation for Fasn in all the evaluated generations. The diet with higher omega-3/omega-6
\end{abstract}

Electronic supplementary material The online version of this article (doi:10.1007/s12263-014-0405-7) contains supplementary material, which is available to authorized users.

C. B. Jacometo $(\varangle)$ · F. T. da Rosa · N. J. L. Dionello Department of Animal Science, Agronomy College, Federal University of Pelotas, Campus Universitário, Pelotas,

RS CEP 96010-900, Brazil

e-mail: cbjacometo@gmail.com

C. B. Jacometo - E. Schmitt - L. F. M. Pfeifer - A. Schneider ·

F. Bado - F. T. da Rosa - S. Halfen - F. A. B. Del Pino

M. N. Corrêa

Center of Research, Teaching and Extension in Animal Science

(NUPEEC), Veterinary College, Federal University

of Pelotas, Campus Universitário, Pelotas, RS

CEP 96010-900, Brazil

E. Schmitt - L. F. M. Pfeifer

Brazilian Agricultural Research Corporation, EMBRAPA,

BR 364 - Km 5,5, Porto Velho, RO CEP 76815-800, Brazil ratio decreased triacylglycerol serum levels and resulted in a constant non-esterified fatty acid level. Our results indicated that the PUFAs effect on the modulation of genes related to fatty acid oxidation and lipogenesis is cumulative through generations.

Keywords PUFAs $\cdot$ Ppara $\cdot$ Rxra $\cdot$ Lxra $\cdot$ Srebf $1 \cdot$ Fasn

\section{Introduction}

The programming of health begins before birth and is influenced by maternal health and nutrition. Alterations in the structure and function of maternal tissues during pregnancy can cause changes in fetal metabolic status (Newnham et al. 2002) leading to greater susceptibility of the offspring to some metabolic syndromes such as obesity, hypertension, diabetes and cardiovascular diseases (Langley-Evans 2006). The mechanisms by which a metabolic disorder or unbalanced nutrition during pregnancy

\section{A. Schneider \\ Department of Nutrition, Nutrition College, Federal University of Pelotas, Campus Universitário, Pelotas, RS CEP 96010-610, Brazil \\ F. Bado $\cdot$ S. Halfen $\cdot$ M. N. Corrêa \\ Department of Veterinary Clinics, Veterinary College, Federal \\ University of Pelotas, Campus Universitário, Pelotas, \\ RS CEP 96010-900, Brazil}

\section{F. A. B. Del Pino}

Department of Biochemistry, Federal University of Pelotas,

Campus Universitário, Pelotas, RS CEP 96010-900, Brazil

J. J. Loor

Division of Nutritional Sciences, Department of Animal

Sciences, University of Illinois, Urbana, IL 61801, USA 
influence gene expression and the phenotype of the offspring are mediated by epigenetics (Simmons 2011).

Recently, it has been proposed that nutrients such as long-chain fatty acids could influence offspring development and heath (Cetin et al. 2009). They are major sources of energy, acting to control the fluidity, permeability and conformation of cellular membranes. The polyunsaturated fatty acids (PUFAs) are especially important because they serve as precursors of important bioactive compounds such as prostacyclins, prostaglandins, thromboxanes and leukotrienes besides their role in structural functions (Haggarty 2010). During pregnancy in mammals, PUFAs are required for embryo (Haggarty et al. 2006) and oocyte development (Matorras et al. 1998), cell growth (Sellmayer et al. 1996) and differentiation (Ding et al. 2002). In this regard, studies have suggested the need for feeding different ratios of omega-6 ( $\omega-6)$ and omega-3 ( $\omega-3)$ during pregnancy (Simopoulos 2002; Simopoulos et al. 1999; Kris-Etherton et al. 2000). For instance, offspring of dams fed with a high-lard (i.e., saturated fat) diet during pregnancy and lactation were more susceptible to metabolic syndrome, including dyslipidemia, increased blood pressure and adiposity (Armitage et al. 2005). Recently, it was demonstrated that a high omega-3 diet reversed the hypertension, hyperlipidemia and adiposity that was induced by consumption of a high fat diet from weaning in 6-month-old male Wistar rats (Zulkafli et al. 2013).

A number of studies have demonstrated the potential of the $\omega-3$ family of PUFAs to regulate key transcription factors controlling hepatic lipid metabolism (Jump 2008; Di Minno et al. 2012). The main target nuclear receptors for this fatty acids are the peroxisome proliferator-activated receptors (Ppar $\alpha, \beta, \gamma 1$ and $\gamma 2$ ), sterol regulatory element binding transcription factor 1 (Srebf1), retinoid $\mathrm{X}$ receptor alpha $(\operatorname{Rxr} \alpha)$ and nuclear receptor, subfamily 1 , group $\mathrm{H}$, member $3(\mathrm{Nr} 1 \mathrm{~h} 3)$, also known as liver $\mathrm{X}$ receptor alpha (Lxr $\alpha$ ) (Jump et al. 2005; Jump 2008).

Ppara is the most abundant PPAR isotype in the liver (Pegorier et al. 2004), and when activated by PUFAs it enhances the expression of genes related to fatty acid oxidation (Jump 2008) such as carnitine palmitoyltransferase 1a (Cpt1a), which is the hepatic Cpt isoform that catalyzes the transport of long-chain acyl-CoA from cytoplasm to the mitochondrial matrix by the conversion of long-chain acyl-CoA to acylcarnitines in order to go through $\beta$-beta oxidation (Sadana et al. 2007). Acyl-CoA oxidase 1 (Acox1) is another enzyme that takes part in the catabolism of straight-chain acyl-CoAs through peroxisomal $\beta$-oxidation (Kassam et al. 2001), and acyl-CoA dehydrogenase very long chain (Acadvl) is a target gene also involved in the mitochondrial $\beta$-oxidation pathway (Spiekerkoetter and Wood 2010). The modulation of Ppara target gene transcription is due to the binding of the
Table 1 Ingredient composition of the experimental diets $(\mathrm{g} / \mathrm{kg}$ diet)

\begin{tabular}{lcc}
\hline Ingredient & \multicolumn{2}{l}{ AIN-93G $(\mathrm{g} / \mathrm{kg}$ diet $)$} \\
\cline { 2 - 3 } & $\mathrm{H}$ & $\mathrm{C}$ \\
\hline Cornstarch & 407.15 & 397.48 \\
Casein & 200.00 & 200.00 \\
Dextrinized cornstarch & 132.00 & 132.00 \\
Sucrose & 100.00 & 100.00 \\
Soybean oil & 0.00 & 70.00 \\
Flaxseed oil & 60.33 & 0.00 \\
Fiber & 50.00 & 50.00 \\
Mineral mix & 35.00 & 35.00 \\
Vitamin mix & 10.00 & 10.00 \\
L-Cystine & 3.00 & 3.00 \\
Choline bitartrate & 2.50 & 2.50 \\
Tert-butylhydroquinone & 0.014 & 0.014 \\
\hline
\end{tabular}

activated heterodimer Ppar/Rxr to a specific DNA sequence, the peroxisome proliferator responsive element (PPRE) (Olefsky 2001).

While PUFAs promote Ppar activation, enhancing fatty acid oxidation, they suppress Srebf1, inhibiting lipogenesis (Jump 2008). Studies demonstrated that a decrease in Srebf1 transcription leads to hepatic inhibition of critical enzyme for lipogenesis (Teran-Garcia et al. 2007), as fatty acid synthase (Fasn) and acetyl-CoA carboxylase alpha (Acaca) (Ronnebaum et al. 2008).

Some investigations have evaluated the effect of prenatal nutrition with PUFAs on metabolic pathways and gene regulation of lipid metabolism, and whether alterations could be transmitted between generations (Armitage et al. 2005; Burdge et al. 2007; Moon et al. 2013). Apart from previously established evidence that dietary PUFAs have an effect on the regulation of hepatic gene expression related to lipid metabolism, the multigenerational effect of the $\omega-3 / \omega-6$ ratio during pregnancy on the offspring metabolism has not yet been established. Therefore, our objective was to evaluate the effect of diets with different $\omega-3 / \omega-6$ ratio in successive generations on blood parameters and hepatic expression level of some nuclear receptors and target genes involved in lipid metabolism.

\section{Materials and methods}

Animals, diets and experimental procedures

Male and female Wistar rats, 8 weeks old, were obtained from Central Vivarium/UFPel. Animals were housed individually in a temperature- $\left(21-23{ }^{\circ} \mathrm{C}\right)$ and humiditycontrolled $(60-70 \%)$ room with $12: 12 \mathrm{~h}$ light-dark 
Fig. 1 Schematic design describing the division of the groups and all the experimental procedures in a chronological line

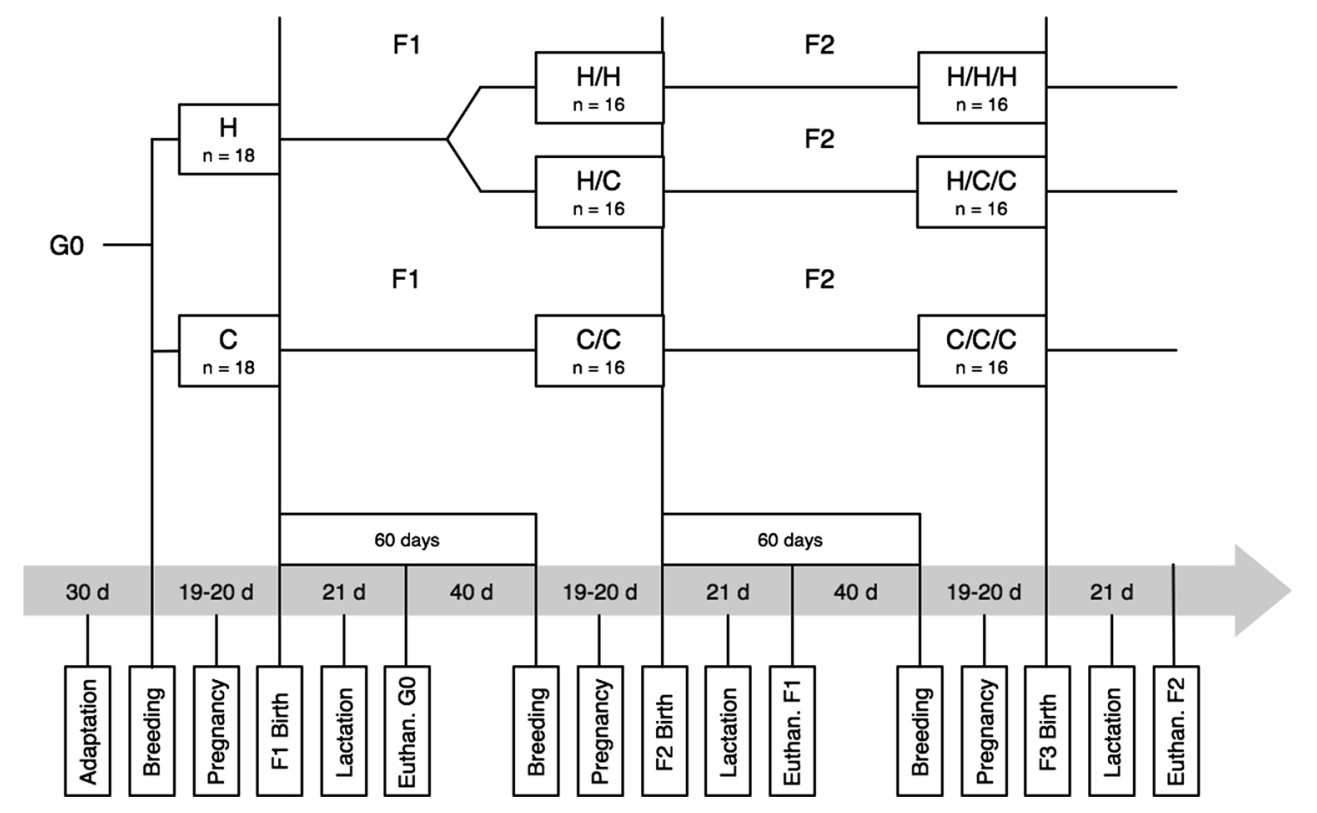

cycling (lights from 6 a.m. to 6 p.m.) and free access to a pelleted diet and water. The diets were elaborated in accordance with AIN-93G recommendations (AIN-93G for growth, pregnancy and lactation) (Reeves et al. 1993; Table 1). Food intake was recorded daily.

The founder generation (G0) was composed of thirty-six females that were randomly assigned to one of two groups: (1) rats fed with a diet elaborated with flaxseed oil, with a high $\omega-3 / \omega-6$ ratio (2.44/1) (H Group, $n=18$ ), and (2) rats fed with a control diet elaborated with soybean oil, with lower $\omega-3 / \omega-6$ ratio $(0.07 / 1)$ (C Group, $n=18$ ). During the experiment, the males received only the control diet. The animals were acclimatized to housing and diets for 30 days. Shortly thereafter, the females were mated in a male:female ratio of $1: 3$ for 3 days. Dam weight was recorded weekly. The number and weight of offspring were recorded at birth, and offspring development was assessed by weighing the group of pups weekly. From the G0 offspring, female progeny were sorted at weaning (21 days) to compose the F1 generation and then divided into three groups: (1) females from the $\mathrm{H}$ group that continued receiving the diet with high $\omega-3 / \omega-6$ ratio $(\mathrm{H} / \mathrm{H}, n=16)$; (2) females from the $\mathrm{H}$ group that began to receive the control diet $(\mathrm{H} / \mathrm{C}, n=16)$; and (3) females from the $\mathrm{C}$ group that continued to receive the diet with lower $\omega-3 / \omega-6$ ratio $(\mathrm{C} / \mathrm{C}, n=16)$. Sixteen males were selected from the $\mathrm{C}$ group. The animals were fed the diets for 60 days and then were mated as described above. From the F1 offspring, female progeny were selected at weaning (21 days) to compose the $\mathrm{F} 2$ generation, and the diet groups were maintained: (1) $\mathrm{H} / \mathrm{H} / \mathrm{H}, n=16$; (2) $\mathrm{H} / \mathrm{C} / \mathrm{C}, n=16$; and (3) $\mathrm{C} / \mathrm{C} / \mathrm{C}, n=16$. To generate the $\mathrm{F} 3$ generation, we followed the same approach as above for the F2 generation. A schematic design of the experimental groups can be found in Fig. 1. All females were evaluated for pregnancy rate, number of pups per litter and average weight at birth.

Diet analysis

Every week a portion of the diet was randomly sampled for chemical analyses and fatty acid profile. The fat was isolated by the Bligh and Dyer method (Bligh and Dyer 1959) and the fatty acid profile analyzed by gas chromatography.

Blood sample and biochemical analysis

At the weaning day, females (with approximately 110 days old) were fasted for $12 \mathrm{~h}$ overnight, and then they were anaesthetized and euthanized according to the protocol approved by the University Animal Care and Use Committee. Blood was collected by intracardiac puncture in clean and EDTA-FK containing tubes. The samples were collected for measurement of plasma concentration of glucose, triacylglycerol (TAG) and non-esterified fatty acids (NEFA). Upon collection, samples were centrifuged at $3,000 \times g$ for $15 \mathrm{~min}$. Plasma was harvested and stored at $-80{ }^{\circ} \mathrm{C}$ until analyzed. The metabolites were analyzed using commercial biochemical assay kits, Glucose PAP Liquiform and Triacylglycerol (Labtest Diagnostica, Brazil) in a visible light spectrophotometer (Biospectro SP 220) and NEFA (Wako, USA) in a microplate reader (Thermo Plate Reader). All samples were analyzed in a single batch and intra-assay coefficient of variation was below $10 \%$. 
Table 2 Primers sequence used for qRT-PCR, source and accession number at NCBI site

\begin{tabular}{|c|c|c|c|c|}
\hline Gene & Forward primer $\left(5^{\prime}-3^{\prime}\right)$ & Reverse primer $\left(5^{\prime}-3^{\prime}\right)$ & Source & Accession no. \\
\hline Ppara & TGGAGTCCACGCATGTGAAG & CGCCAGCTTTAGCCGAATAG & Somm et al. (2009) & NM_013196.1 \\
\hline Rxra & GGACACCAAACATTTCCTGCC & GATGTGCTTGGTGAAGGA & Gillio-Meina et al. (2009) & NM_012805.2 \\
\hline Lxra & AGGAGTGTCGACTTCGCAAA & CTCTTCTTGCCGCTTCAGTTT & Cha and Repa (2007) & NM_031627.2 \\
\hline Srebf 1 & GGAGCCATGGATTGCACATT & GGCCCGGGAAGTCACTGT & Cha and Repa (2007) & XM_213329.6 \\
\hline Acox 1 & GGCATGTAACCCGTAGCACT & GCCCAACTGTGACTTCCATT & Baarine et al. (2012) & NM_017340.2 \\
\hline Cpt1a & CTCCGCCTGAGCCATGAAG & CACCAGTGATGATGCCATTCT & Yang et al. (2011) & NM_031559.2 \\
\hline Acadvl & ATGACCCTGCCAAGAATGAC & TCCCAGGGTAACGCTAACAC & Buettner et al. (2006) & NM_012891.2 \\
\hline Fasn & CAGGTGTGTGATGGGAAGG & CCGTACACTCACTCGAGGC & Hansmannel et al. (2006) & NM_017332.1 \\
\hline Acaca & GCCATCCGGTTTGTTGTCA & GGATACCTGCAGTTTGAGCCA & Ronnebaum et al. (2008) & NM_022193.1 \\
\hline Ncor 1 & AGTCGCTACAGCCCAGAGTC & СTCCTCTCTGGGGATTTTCC & Malik et al. (2010) & XM_577103.4 \\
\hline Actb & TGTCACCAACTGGGACGATA & GGGGTGTTGAAGGTCTCAAA & Bonefeld et al. (2008) & NM_031144.3 \\
\hline Gapdh & ACCACAGTCCATGCCATCAC & TCCACCACCCTGTTGCTGTA & Nelissen et al. (2010) & NM_017008.4 \\
\hline Rn18 s & ACGGACCAGAGCGAAAGCAT & TGTCAATCCTGTCCGTGTCC & Bonefeld et al. (2008) & NR_046237.1 \\
\hline
\end{tabular}

Tissue collection, RNA isolation and qRT-PCR analyses

Six female per group, with 21 days postpartum, were euthanized in each of the three generations $(\mathrm{G} 0, \mathrm{~F} 1$ and F2). Immediately after euthanasia the liver was collected, stored in cryotubes and snap-frozen by submerging in liquid nitrogen. Total RNA was isolated from the liver samples using TRIzol reagent (Invitrogen, USA) according to the manufacturer's instructions. Total RNA was purified using RNeasy columns and on-column RNase-free DNase treatment (Qiagen, Germany), following the manufacturer's protocol. The absence of RNA degradation was checked on a $1 \%$ Tris-borate-EDTA buffer/agarose gel analyzing $28 \mathrm{~S}$ and $18 \mathrm{~S}$ rRNA subunits, after electrophoresis in $80 \mathrm{~V}$ during $1.5 \mathrm{~h}$. The purity and concentration were measured with an UV spectrophotometer (UV Mini 1240, Shimadzu). The A260/A280 ratio was used as an indication of RNA quality. Reverse transcription was carried out with $1 \mu \mathrm{g}$ of RNA using the High Capacity cDNA Reverse Transcription Kit with RNase Inhibitor (Applied Biosystems, USA) in a $10 \mu \mathrm{L}$ volume. The reaction was performed in a thermo cycler (MyCycleTM Thermo Cycler, Bio Rad) using the following temperatures: $25^{\circ} \mathrm{C}$ for $10 \mathrm{~min}, 37^{\circ} \mathrm{C}$ for $120 \mathrm{~min}$ and $85{ }^{\circ} \mathrm{C}$ for $5 \mathrm{~min}$. The cDNA was then diluted to $5 \mathrm{ng} / \mu \mathrm{L}$.

Real-time quantitative PCR using SYBR Green dye was used to evaluate Ppara, Rxra, Cpt1a, Acox1, Acadvl, Lxra, Srebf1, Fasn, Acaca and Ncor1 gene expression. Actin beta (Actb), Glyceraldehyde-3-phosphate dehydrogenase (Gap$\mathrm{dh}$ ) and $18 \mathrm{~S}$ ribosomal RNA (Rn18 s) were used as internal controls and the geometric mean calculated and used to normalize data. The primer sequences and references are shown in Table 2. qPCR was performed using $4 \mu \mathrm{L}$ diluted cDNA, $5 \mu \mathrm{L}$ of $1 \times$ SYBR Green master mix (Applied
Biosystems, USA), $0.4 \mu \mathrm{L}$ of each of $10 \mu \mathrm{M}$ forward and reverse primers, and $0.2 \mu \mathrm{L}$ of DNase- and RNase-free water in MicroAmpTM Optical 96-Well Reaction Plate (Applied Biosystems, USA). Each sample was run in triplicate, and a 6-point relative standard curve was generated using serial dilutions of cDNA prepared from liver samples to calculate efficiency of each primer pair. Each assay plate included a negative control in triplicate. The $\mathrm{CV}$ was below $10 \%$ for all the primer pairs used. The reactions were performed in an ABI Prism 7500-Fast instrument (Applied Biosystems, USA) using the following conditions: $2 \mathrm{~min}$ at $50{ }^{\circ} \mathrm{C}, 10 \mathrm{~min}$ at $95{ }^{\circ} \mathrm{C}, 40$ cycles of $15 \mathrm{~s}$ at $95^{\circ} \mathrm{C}, 30 \mathrm{~s}$ at $60{ }^{\circ} \mathrm{C}$ and $30 \mathrm{~s}$ at $72{ }^{\circ} \mathrm{C}$, a final extension for $5 \mathrm{~min}$ followed for a melting curve stage $\left(15 \mathrm{~s}\right.$ at $95{ }^{\circ} \mathrm{C}, 1 \mathrm{~min}$ at $60^{\circ} \mathrm{c}, 30 \mathrm{~s}$ at $95^{\circ} \mathrm{C}$ and $15 \mathrm{~s}$ at $\left.60{ }^{\circ} \mathrm{C}\right)$. mRNA abundance (A) was calculated as $\mathrm{A}=1 /$ efficiency $\Delta \mathrm{CT}$, where $\Delta \mathrm{CT}=$ sample $\mathrm{CT}-$ geometric mean of the 3 housekeeping genes (Bionaz et al. 2012).

\section{Statistical analyses}

The results are presented as mean \pm SEM. All the statistical analyses were performed using SAS (SAS Institute Inc, Cary, NC, USA). Data (mRNA abundance) were log transformed prior to statistical analysis. The pregnancy rate was compared among groups and generations by Chisquare. Diet consumption, diet fatty acid profile, number and weight of pups were compared by one-way ANOVA and Tukey test. For biochemical parameters and mRNA abundance the Mixed Model procedure was used, considering the effects of diet, generation, and its interactions. A value of $P<0.05$ was considered statistically significant. To the groups $\mathrm{H} / \mathrm{C}(\mathrm{F} 1)$ and $\mathrm{H} / \mathrm{C} / \mathrm{C}(\mathrm{F} 2)$, the $\mathrm{H}$ group (G0) was taken as the founder generation, as they were derived from it (see Fig. 1). 
(a) Ppara

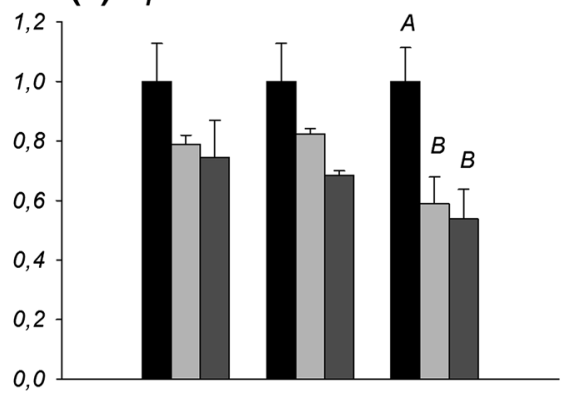

(b) Cpt1a

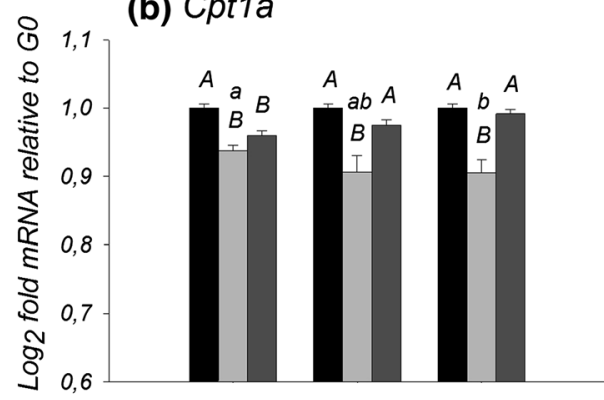

(c) Acadvl
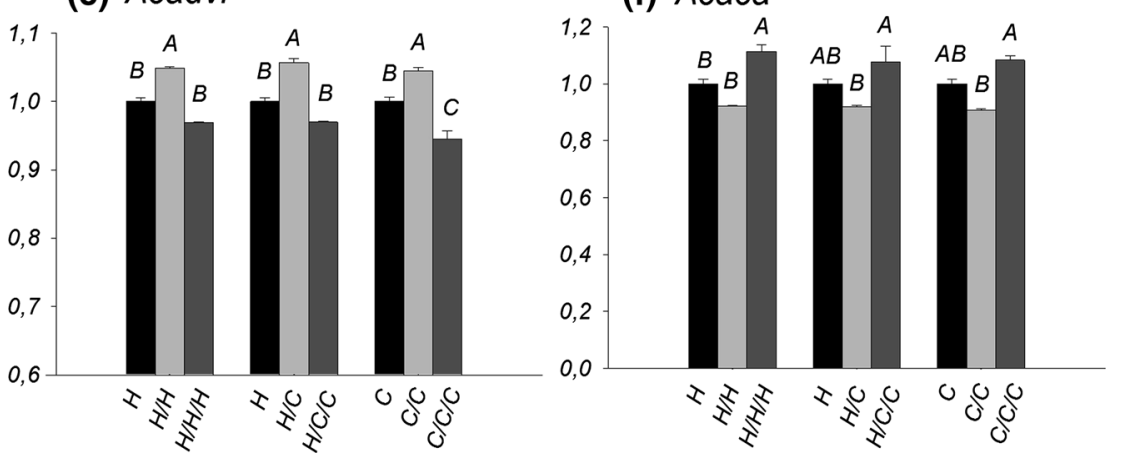

(g) Srebf1

(d) Rxra

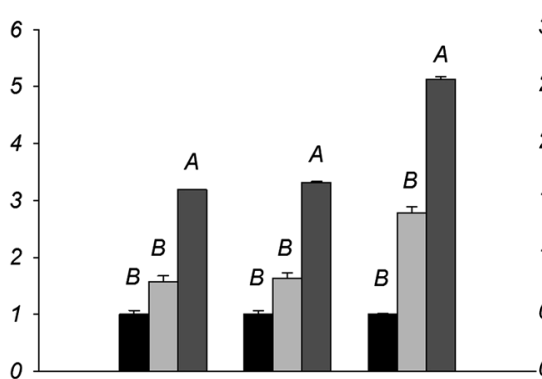

(e) Lxra

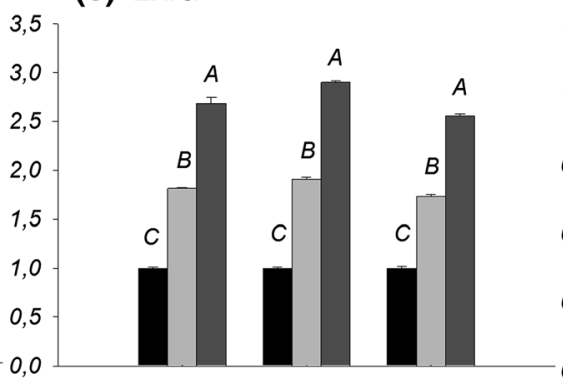

(h) Fasn
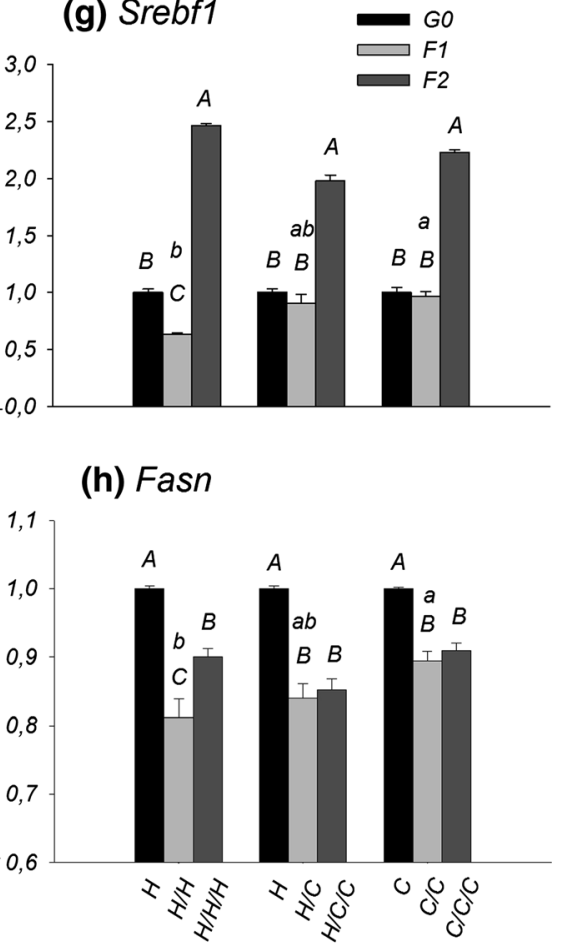

Fig. 2 mRNA fold change of the $\mathrm{H}, \mathrm{H} / \mathrm{C}$ and $\mathrm{C}$ groups, in $\mathrm{F} 1$ and $\mathrm{F} 2$ relative to the G0 for a Ppara, b Cpt1a, c Acadvl, d Rxra, e Lxra, $\mathbf{f}$ Acaca, $\mathbf{g}$ Srebf1, h Fasn. Capital letters indicate differences between

\section{Results}

Fatty acid oxidation genes

Diet did not elicit a difference in Ppara $(P>0.05)$ and Rxra expression $(P>0.05)$. Regarding Ppara target genes Cpt1a, Acadvl and Acox1, a diet effect was only observed in the F1 generation for $\mathrm{Cptla}$, where the $\mathrm{H} / \mathrm{H}$ group had greater expression $(P=0.011)$ than the $\mathrm{C} / \mathrm{C}$ group (Fig. $2 \mathrm{~b}$ ).

The generational effect in Ppara expression was observed in the $\mathrm{C}$ group, with a reduction from $\mathrm{G} 0$ to $\mathrm{F} 1$ $(P=0.05)$ and G0 to F2 $(P=0.03)$ (Fig. 2a). For Rxra, all groups did not have difference from G0 to $F 1$, but had a significant increase in the $\mathrm{F} 2$ expression, $\mathrm{H}$ (G0-F2: $P<0.001$ and F1-F2: $P=0.044), \quad \mathrm{H} / \mathrm{C} \quad(\mathrm{G} 0-\mathrm{F} 2$ : $P<0.001$ and $\mathrm{F} 1-\mathrm{F} 2: P=0.009)$ and $\mathrm{C}$ group $(\mathrm{G} 0-\mathrm{F} 2$ : generations in the same group $(P<0.05)$. Lowercase letters indicate differences between groups in the same generation $(P<0.05)$

$P<0.001$ and F1-F2: $P=0.011$ ) (Fig. 2d). Along generations the expression of Acadvl was opposite to Cpt1a, while for Cptla there was a decrease from G0 to $\mathrm{F} 1(\mathrm{H}$, $P=0.003$; H/C, $P<0.001 ; \mathrm{C}, P<0.001)$ followed by an increase from $\mathrm{F} 1$ to $\mathrm{F} 2(\mathrm{H} / \mathrm{C}, P<0.001$; $\mathrm{C}, P<0.001)$ (Fig. 2b), for Acadvl there was an increase from G0 to F1 (H, $P=0.020 ; \mathrm{H} / \mathrm{C}, P=0.003 ; \mathrm{C}, P=0.034)$ and then a decrease from $\mathrm{F} 1$ to $\mathrm{F} 2 \quad(P<0.001$ for all groups $)$ (Fig. 2c). No generational effect was observed in Acox1 expression $(P>0.05$ - see supplemental Fig. 1).

Lipogenic genes

A difference of Srebf1 mRNA expression between groups can be observed only in the $\mathrm{F} 1$ generation, where $\mathrm{C} / \mathrm{C}$ group had a greater expression than the $\mathrm{H} / \mathrm{H}$ group 


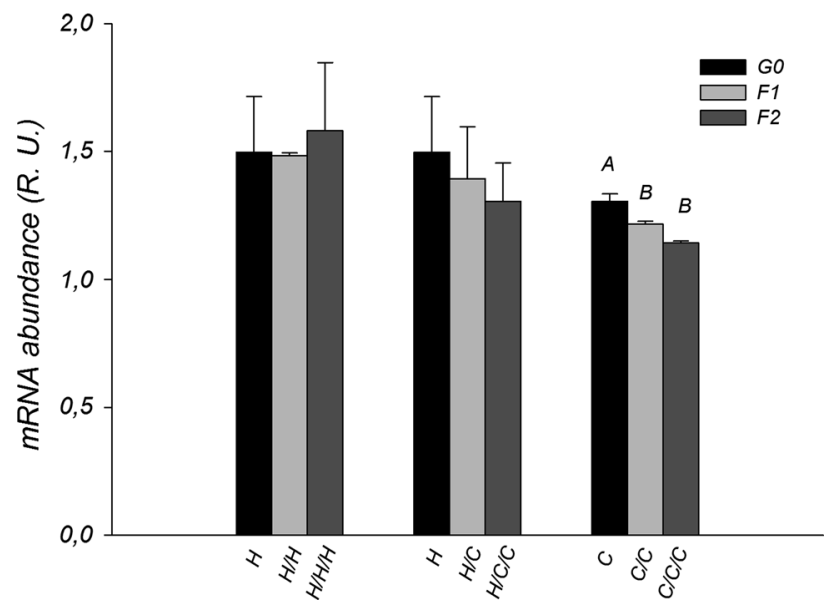

Fig. 3 NCor1 mRNA abundance (relative units) of the $\mathrm{H}, \mathrm{H} / \mathrm{C}$ and $\mathrm{C}$ groups along generations. Capital letters indicate differences between generations in the same group $(P<0.05)$

$(P=0.019)$ (Fig. 2g). Regarding the target genes, differences between groups were observed only for Fasn, in the $\mathrm{F} 1$ generation, where the $\mathrm{C} / \mathrm{C}$ group had greater $(P=0.006)$ expression than the $\mathrm{H} / \mathrm{H}$ group (Fig. $2 \mathrm{~h}$ ).

The generational effect could be observed in the increasing expression of Lxra in all groups, $\mathrm{H}(\mathrm{G} 0-\mathrm{F} 1$ : $P<0.001, \mathrm{G} 0-\mathrm{F} 2: P<0.001$ and $\mathrm{F} 1-\mathrm{F} 2: P=0.023)$, H/C $(\mathrm{G} 0-\mathrm{F} 1: P<0.001, \mathrm{G} 0-\mathrm{F} 2: P<0.001$ and $\mathrm{F} 1-\mathrm{F} 2$ : $P=0.001)$ and $\mathrm{C}(\mathrm{G} 0-\mathrm{F} 1: P<0.001, \mathrm{G} 0-\mathrm{F} 2: P<0.001$ and F1-F2: $P=0.002$ ) (Fig. 2e). The hepatic expression of Srebf1 of the $\mathrm{H}$ group decreased between $\mathrm{G} 0$ to $\mathrm{F} 1$ $(P=0.035)$ followed by an increase between G0 to F2 $(P<0.001)$ and $\mathrm{F} 1$ to $\mathrm{F} 2(P<0.001)$. The groups $\mathrm{H} / \mathrm{C}$ and $\mathrm{C}$ had no differences between $\mathrm{G} 0$ to $\mathrm{F} 1$; however, the expression of Srebf1 increased significantly in F2 generation compared to $\mathrm{F} 1$ and $\mathrm{G} 0$ generations $(P<0.001$ for all comparisons) (Fig. 2g).

For Fasn, all the groups had a very similar profile, a decrease between G0 to F1 $(P<0.001$ for all groups) and also $\mathrm{G} 0$ to $\mathrm{F} 2(\mathrm{H}, P<0.001 ; \mathrm{H} / \mathrm{C}, P<0.001 ; \mathrm{C}$, $P=0.004)$. Only in the $\mathrm{H}$ group expression increased $(P=0.002)$ from $\mathrm{F} 1$ to $\mathrm{F} 2$ (Fig. $2 \mathrm{~h})$. For Acaca, an increase $(\mathrm{H}, P=0.001 ; \mathrm{H} / \mathrm{C}, P=0.002 ; \mathrm{C}, P<0.001)$ was observed in all groups between $\mathrm{F} 1$ to $\mathrm{F} 2$ (Fig. 2i).

\section{Nuclear co-repressor expression}

No diet effect was observed in the regulation of NCor1 $(P>0.05)$. Along generations only the $\mathrm{C}$ group was affected, demonstrating a decrease in the expression between $\mathrm{G} 0$ and the other generations (F1: $P=0.027$ and F2: $P<0.001$ ) (Fig. 3).
Table 3 Fatty acid profile of the experimental diets (percentage of each fatty acid)

\begin{tabular}{|c|c|c|}
\hline \multirow[t]{2}{*}{ Fatty acids } & \multicolumn{2}{|l|}{ Diets } \\
\hline & $\mathrm{H}$ (flaxseed oil) & C (soybean oil) \\
\hline$\omega-3: \omega-6$ ratio & $2.44 / 1^{\mathrm{b}}$ & $0.07 / 1^{\mathrm{a}}$ \\
\hline Polyunsaturated & $61.11 \pm 0.742^{\mathrm{a}}$ & $49.52 \pm 0.791^{\mathrm{b}}$ \\
\hline Linoleic $\left(\mathrm{C}_{18: 2}\right)$ & $17.75 \pm 1.180^{\mathrm{b}}$ & $45.99 \pm 0.540^{\mathrm{a}}$ \\
\hline$\alpha$-Linolenic $\left(\mathrm{C}_{18: 3}\right)$ & $43.26 \pm 1.849^{\mathrm{a}}$ & $3.39 \pm 0.384^{\mathrm{b}}$ \\
\hline Eicosadienoic $\left(\mathrm{C}_{20: 2}\right)$ & $0.04 \pm 0.005^{\mathrm{b}}$ & $0.07 \pm 0.013^{\mathrm{a}}$ \\
\hline Eicosatrienoic $\left(\mathrm{C}_{20: 3}\right)$ & $0.04 \pm 0.003$ & $0.04 \pm 0.010$ \\
\hline Eicosapentaenoic $\left(\mathrm{C}_{20: 5}\right)$ & $0.02 \pm 0.011$ & $0.03 \pm 0.021$ \\
\hline Monounsaturated & $20.68 \pm 0.486^{\mathrm{b}}$ & $27.74 \pm 0.582^{\mathrm{a}}$ \\
\hline Palmitoleic $\left(\mathrm{C}_{16: 1}\right)$ & $0.18 \pm 0.003^{\mathrm{a}}$ & $0.16 \pm 0.004^{\mathrm{b}}$ \\
\hline Cis-10-heptadecanoic $\left(\mathrm{C}_{17: 1}\right)$ & $0.03 \pm 0.006$ & $0.04 \pm 0.006$ \\
\hline Oleic $\left(\mathrm{C}_{18: 1}\right)$ & $20.33 \pm 0.477^{\mathrm{b}}$ & $27.14 \pm 0.571^{\mathrm{a}}$ \\
\hline Eicosenoic $\left(\mathrm{C}_{20: 1}\right)$ & $0.14 \pm 0.022^{\mathrm{b}}$ & $0.41 \pm 0.061^{\mathrm{a}}$ \\
\hline Saturated & $14.87 \pm 0.299^{\mathrm{b}}$ & $17.83 \pm 0.298^{\mathrm{a}}$ \\
\hline Caproic $\left(\mathrm{C}_{6: 0}\right)$ & $0.08 \pm 0.054$ & $0.03 \pm 0.009$ \\
\hline Caprylic $\left(\mathrm{C}_{8: 0}\right)$ & $0.04 \pm 0.015$ & $0.02 \pm 0.003$ \\
\hline Capric $\left(\mathrm{C}_{10: 0}\right)$ & $0.06 \pm 0.002^{\mathrm{a}}$ & $0.05 \pm 0.002^{\mathrm{b}}$ \\
\hline Lauric $\left(\mathrm{C}_{12: 0}\right)$ & $0.06 \pm 0.002^{\mathrm{a}}$ & $0.05 \pm 0.002^{\mathrm{b}}$ \\
\hline Myristic $\left(\mathrm{C}_{14: 0}\right)$ & $0.37 \pm 0.006^{\mathrm{a}}$ & $0.33 \pm 0.010^{\mathrm{b}}$ \\
\hline Pentadecanoate $\left(\mathrm{C}_{15: 0}\right)$ & $0.08 \pm 0.001^{\mathrm{a}}$ & $0.06 \pm 0.001^{\mathrm{b}}$ \\
\hline Palmitic $\left(\mathrm{C}_{16: 0}\right)$ & $7.69 \pm 0.185^{\mathrm{b}}$ & $11.00 \pm 0.060^{\mathrm{a}}$ \\
\hline Heptadecanoic $\left(\mathrm{C}_{17: 0}\right)$ & $0.10 \pm 0.001^{\mathrm{b}}$ & $0.11 \pm 0.001^{\mathrm{a}}$ \\
\hline Stearic $\left(\mathrm{C}_{18: 0}\right)$ & $5.58 \pm 0.123^{\mathrm{a}}$ & $4.57 \pm 0.162^{\mathrm{b}}$ \\
\hline Arachidic $\left(\mathrm{C}_{20: 0}\right)$ & $0.40 \pm 0.105^{\mathrm{b}}$ & $0.80 \pm 0.256^{\mathrm{a}}$ \\
\hline Behenic $\left(\mathrm{C}_{22: 0}\right)$ & $0.24 \pm 0.017^{\mathrm{b}}$ & $0.56 \pm 0.012^{\mathrm{a}}$ \\
\hline Tricosanoic $\left(\mathrm{C}_{23: 0}\right)$ & $0.05 \pm 0.002^{\mathrm{b}}$ & $0.06 \pm 0.007^{\mathrm{a}}$ \\
\hline Lignoceric $\left(\mathrm{C}_{24: 0}\right)$ & $0.12 \pm 0.015$ & $0.16 \pm 0.024$ \\
\hline Heneicosanoic $\left(\mathrm{C}_{21: 0}\right)$ & $0.01 \pm 0.002^{\mathrm{b}}$ & $0.03 \pm 0.003^{\mathrm{a}}$ \\
\hline
\end{tabular}

a,b Significative differences of fatty acid proportion between diets $(P<0.05)$

Dietary fatty acid profile and intake

The ratio $\omega 3 / \omega 6$ was $2.44 / 1$ in the $\mathrm{H}$ diet and $0.07 / 1$ in the $\mathrm{C}$ diet. Saturated and monosaturated fatty acid percentage was greater $(P<0.05)$ in the $\mathrm{C}$ diet, while the PUFAs was greater $(P<0.05)$ in the $\mathrm{H}$ diet. The $\alpha$-linolenic acid (ALA) was almost 13 times greater in the $\mathrm{H}$ diet, as the linoleic acid (LA) was more than double in the $\mathrm{C}$ diet (Table 3). Every day the diet consumption was recorded, and we could confirm that the diet fatty acid profile did not affect food intake $(P>0.05)$. The mean daily food intake for G0 (adaptation period until weaning) was $20.0 \pm 1.0 \mathrm{~g}$ for $\mathrm{H}$ group and $20.5 \pm 1.0 \mathrm{~g}$ for the $\mathrm{C}$ group; the $\mathrm{F} 1$ (from its weaning until the $\mathrm{F} 2$ weaning) intake was $16.1 \pm 0.8 \mathrm{~g}$ for the $\mathrm{H} / \mathrm{H}$ group, $15.4 \pm 0.8 \mathrm{~g}$ for the $\mathrm{H} / \mathrm{C}$ group and $16.9 \pm 0.7 \mathrm{~g}$ for the $\mathrm{C} / \mathrm{C}$ group; and the $\mathrm{F} 2$ (from its weaning until the $\mathrm{F} 3$ weaning) was $18.0 \pm 1.0 \mathrm{~g}$ for the 
Table 4 Blood serum concentration (mmol/L) of glucose, triacylglycerol (TAG) and non-esterified fatty acids (NEFA)

\begin{tabular}{lllll}
\hline Generation & Group & Glucose & TAG & NEFA \\
\hline G0 & H & $129.15 \pm 9.47$ & $71.75 \pm 7.03$ & $0.325 \pm 0.021$ \\
& C & $138.75 \pm 8.63$ & $80.21 \pm 13.39^{\mathrm{B}}$ & $0.343 \pm 0.031^{\mathrm{B}}$ \\
F1 & $\mathrm{H} / \mathrm{H}$ & $128.68 \pm 2.98$ & $49.89 \pm 16.02$ & $0.327 \pm 0.025$ \\
& $\mathrm{H} / \mathrm{C}$ & $119.96 \pm 2.34$ & $60.41 \pm 11.78^{\mathrm{C}}$ & $0.268 \pm 0.026$ \\
$\mathrm{C} / \mathrm{C}$ & $130.85 \pm 10.98$ & $57.93 \pm 8.56^{\mathrm{b}}$ & $0.258 \pm 0035^{\mathrm{B}}$ \\
F2 & H/H/H & $141.054 \pm 4.51$ & $86.80 \pm 11.60^{\mathrm{ab}}$ & $0.329 \pm 0.035^{\mathrm{b}}$ \\
& H/C/C & $166.83 \pm 12.11$ & $109.25 \pm 16.01^{\text {Aa }}$ & $0.220 \pm 0.007^{\mathrm{c}}$ \\
& C/C/C & $144.18 \pm 4.43$ & $0.417 \pm 0.034^{\text {Aa }}$ \\
\hline
\end{tabular}

Capital letters indicate differences between generations in the same group $(P<0.05)$. Lowercase letters indicate differences between groups in the same generation $(P<0.05)$

$\mathrm{H} / \mathrm{H} / \mathrm{H}$ group, $19.7 \pm 0.7 \mathrm{~g}$ for the $\mathrm{H} / \mathrm{C} / \mathrm{C}$ group and $17.6 \pm 0.9 \mathrm{~g}$ for the $\mathrm{C} / \mathrm{C} / \mathrm{C}$ group.

\section{Blood metabolites}

The blood biochemical analyses indicated that the fatty acid profile of the diet did not influence the glucose levels, as they were similar among the groups and generations, showing normoglycemic levels. The omega-3 rich diet decreased TAG in the F2 $(P=0.04)$ compared with the females that were receiving the $\mathrm{C}$ diet in $\mathrm{F} 2$ generation. $\mathrm{A}$ generation effect was observed for TAG concentrations in the $\mathrm{C}$ group, and there was a reduction comparing $\mathrm{G} 0$ to $\mathrm{F} 1$ $(P<0.0001)$ and an increase in F2 (G0-F2: $P<0.01, \mathrm{~F} 1-$ F2: $P=0.02)$, while the other groups maintained constant levels. Regarding NEFA, differences between groups were also only observed in the $\mathrm{F} 2$ generation, where the $\mathrm{C} / \mathrm{C} / \mathrm{C}$ group had greater NEFA concentration than the $\mathrm{H} / \mathrm{H} / \mathrm{H}$ group $(P=0.02)$, which in turn had greater concentration than the $\mathrm{H} / \mathrm{C} / \mathrm{C}$ group $(P=0.005)$. We must highlight that although differences were observed between generations, the animals that received the $\mathrm{H}$ diet maintained a constant concentration of NEFA, while the $\mathrm{C}$ group had a decrease in concentration from G0 to $\mathrm{F} 1(P=0.04)$ and increased from $\mathrm{F} 1$ to $\mathrm{F} 2(P=0.005)$. These parameters are shown in Table 4.

\section{Reproductive parameters and body weight}

The pregnancy rate was similar between the groups throughout the generations (G0, F1 and F2 $-P>0.05)$ and were in the acceptable range of $62.5-87.5 \%$. There was no effect of dietary treatment on the number of pups per litter $(P>0.05)$, but in the $\mathrm{F} 1$ generation the pup mean weight at birth was greater in the $\mathrm{H} / \mathrm{H}$ group $(7.33 \pm 0.21 \mathrm{~g})$ than the $\mathrm{C} / \mathrm{C}$ group $(6.55 \pm 0.13 \mathrm{~g})(P=0.01)$. Considering the $\mathrm{C}$ group throughout the generations, we observed a reduction $(P=0.01)$ in the pup mean weight from G0
$(7.39 \pm 0.22 \mathrm{~g})$ to $\mathrm{F} 1(6.55 \pm 0.13 \mathrm{~g})$ that was maintained in the F2 (6.88 $\pm 0.41 \mathrm{~g})$.

\section{Discussion}

Over the last three decades, research on fatty acid metabolism, specially PUFAs, have exposed the benefits of these molecules on normal health and chronic diseases, through the regulation of lipid metabolism (Soulimane-Mokhtari et al. 2005; Kagohashi et al. 2010; Makni et al. 2011), cardiovascular (Adkins and Kelley 2010; Tousoulis et al. 2014; de Oliveira Otto et al. 2013) and immune function (Tapia et al. 2014; Yates et al. 2014; Liu et al. 2013). All fetal supply of $\omega-3$ and $\omega-6$ comes from the mother, crossing the placenta, either in the form of the essential fatty acid, or their long-chain PUFAs derivatives (Herrera 2002). The experimental diets offered to the animals in this study contained high amounts of PUFAs, almost $50 \%$ in the $\mathrm{C}$ diet, and more than $60 \%$ in the $\mathrm{H}$ diet. The consumption of food was not affected by the fatty acid profile in accordance with Rice and Corwin (Rice and Corwin 2002). The essential fatty acids offered through the diet were converted to other metabolites and incorporated in the liver in different proportions. The $\mathrm{H}$ group had more ALA and its metabolites, eicosapentaenoic acid (EPA) and docosapentaenoic acid (DHA) than the $\mathrm{C}$ group; while the animals that received the $\mathrm{C}$ diet had greater concentrations of LA and its metabolite arachidonic acid (AA) (data not shown), indicating activity of desaturases and elongases.

Studies demonstrated the existence of an interrelationship between Ppars, Srebf1 and Lxr. More than 10 years ago, in vitro and in vivo experiments proved that PUFAs suppressed Srebf1 activity by inhibition the Lxr/Rxr binding to LXREs (Yoshikawa et al. 2002, 2003). In the present study, only the $\mathrm{C}$ group decreased Ppara mRNA abundance from $\mathrm{G} 0$ to $\mathrm{F} 1$ and $\mathrm{F} 2$ generations, the other groups maintained their expression levels (Fig. 2a). In 
contrast, the expression of Srebf1 increased from G0 through F2 regardless of experimental group. A similar profile was observed for Lxra and Rxra expression, concerning with the studies cited above, providing evidence of the regulation of Srebf1 via Lxra activation. As the level of Ppara did not increase significantly, and Srebf1 did not decrease with a high PUFA diet, we suggest the existence of a post-transcriptional regulatory mechanism controlling fatty acid oxidation and lipogenic function potentially through proteolytic processing and autoloop regulatory circuit (Takeuchi et al. 2010).

In the liver, Ppara activation represses Srebf1 expression (Fernandez-Alvarez et al. 2011) and the decrease in Ppara coupled with the increase in Srebf1 expression across generations seems to support the mechanistic regulation between these transcription factors. Other factors, such as mammalian target of rapamycin complex 1 (mTOC1) (Lewis et al. 2011; Bakan and Laplante 2012; Takashima et al. 2009), protein kinase Akt (Yecies et al. 2011), fibroblast growth factor 21 (FGF21) (Zhang et al. 2011), S6 kinase 1 (S6K1) (Li et al. 2011) and adiponectin (Awazawa et al. 2009) could regulate Srebf1 transcription. Although the insulin response was not evaluated in this study, a higher insulin sensitivity across generations could be acting on the activation of Srebf1 promoter, primarily by increasing the activity of Lxrs or their heterodimerizing partner Rxrs (Chen et al. 2004). In accordance with this, a recent study demonstrated the increase in insulin sensitivity in the second generation of rats exposed to diets with high PUFAs content (Hirabara et al. 2013). The Rxra is intimately linked with Ppara, since its heterodimerization is necessary to activate and to promote the binding to PPRE in target gene promoters (Pegorier et al. 2004), and its increase during the experimental period might have been a response to Lxra and Srebf1.

The observed reduction in Fasn expression over the three generations, even with enhanced Srebf1 expression, seems opposite to the well-known effect of Srebf1 on Fasn expression (Teran-Garcia et al. 2007), suggesting that other factors may be regulating Fasn. One study with canola oil as PUFA source did not report a suppression of lipogenic gene expression, suggesting that diet did not induce liver lipid catabolism nor suppressed lipid synthesis, while a diet with highly unsaturated fatty acids from a fish/fungal source strongly suppressed both pathways (Sealls et al. 2008). Other factors such as growth hormone (GH), prolactin (PRL), STAT5, glucagon and insulin may also participate in the regulation of Fasn expression (Hogan and Stephens 2005; Moon et al. 2002).

Another interesting finding of this study was the opposite behavior of the Cptla and Acadvl genes. We speculate that the decrease from G0 to F1 observed in Cpt1a expression, when there was an increase at the same time point in Acadvl, was a cellular mechanism of regulation in the equilibrium between fatty acid transfer from cytoplasm to the mitochondria and $\beta$-oxidation, a manner to increase fatty acid entrance to supply the reduction in fatty acid oxidation. Related to the expression control exerted by corepressors, PPAR and the evaluated target genes must be under influence of others main co-regulators, as SRC-1 (Dasgupta et al. 2014) and SMRT (Watson et al. 2012), since NCor1 expression level was almost constant. As what was observed with Acox1, a lack of diet and/generational effect on the regulation of their expression.

DNA methylation is the major epigenetic modification that controls gene expression in physiologic and pathologic states (Barres and Zierath 2011). As reviewed by Holness et al., nutrients can cause acute and long-term modifications at the gene expression level and lead to epigenetic modifications (Holness et al. 2010) and a recent study has already indicated epigenetic regulation induced by ALA (Niculescu et al. 2013). In this context, the dietary PUFA may act at the "end" of the process, or by controlling the activity of the nuclear receptors, not their abundance. This phenomenon must be evaluated in the future, so the observed changes in mRNA abundance from this study can be better understood.

The experimental diets did not alter the plasma glucose concentration, in accordance with other recent studies and indicating that chronic feeding of diets rich in PUFAs do not alter the glucose metabolism and its plasma concentration (Rice and Corwin 2002; Mellouk et al. 2012). It has already been shown that feeding animals with $\omega-3$ and $\omega-6$ diets is effective in lowering plasma triacylglycerol levels (de Assis et al. 2012; Harris 1989), as we observed in this experiment. We must highlight the apparent regulation of gene expression and blood metabolites across generations induced in the $\mathrm{C}$ group, indicating that diets with a high concentration of PUFAs, independently of the $\omega-3 / \omega-6$ ratio, can induce metabolic regulation across generations.

About the reproductive parameters, the lack of difference in pregnancy rate between the groups and generations suggests that the ratio between $\omega-6$ and $\omega-3$ did not influence female fertility, similar to a study feeding flaxseed (Leal Soares et al. 2010). The greater pup mean weight of the F1 generation in the group fed with the omega-3 rich diet than controls, which were fed with the omega-6 rich diet, demonstrates that maternal consumption of omega-3 PUFAs during pregnancy had an effect on fetal and offspring growth and development. The reduction in pup mean weight in the control group between G0 to F1, and its maintenance in $\mathrm{F} 2$, indicated that more attention should be given to the $\omega-3 / \omega-6$ ratio during the perinatal period, especially to $\omega-3$ excess and its deleterious effect (Church et al. 2008). Again these results suggest the effects of maternal diet on offspring development. 
In conclusion, feeding animals with PUFAs allowed for an initial study of the transgenerational control of hepatic lipogenesis and metabolism. There is clear evidence of cumulative effects throughout generations, independent of the PUFAs source, at least in part via up and down regulation of lipid metabolism-related genes.

Acknowledgments We thank Dra. Leonor Almeida de Souza Soares for help with the experimental diets and animal handling training. This research was funded by the PNPD Program (2278/2009) from the Coordination for the Improvement of Higher Level- or EducationPersonnel (CAPES).

Conflict of interest Carolina B. Jacometo, Eduardo Schmitt, Luiz F. M. Pfeifer, Augusto Schneider, Francielle Bado, Fernanda T. da Rosa, Simone Halfen, Francisco A. B. Del Pino, Juan J. Loor, Marcio N. Corrêa and Nelson J. L. Dionello declare that they have no conflict of interest.

Ethical standard All institutional and national guidelines for care and use of laboratory animals were followed and the experimental protocol was approved by the Animal Welfare Committee from Federal University of Pelotas (Permit number: 0976).

\section{References}

Adkins Y, Kelley DS (2010) Mechanisms underlying the cardioprotective effects of omega-3 polyunsaturated fatty acids. J Nutr Biochem 21(9):781-792. doi:10.1016/j.jnutbio.2009.12.004

Armitage JA, Taylor PD, Poston L (2005) Experimental models of developmental programming: consequences of exposure to an energy rich diet during development. J Physiol 565(Pt 1):3-8. doi:10.1113/jphysiol.2004.079756

Awazawa M, Ueki K, Inabe K, Yamauchi T, Kaneko K, Okazaki Y, Bardeesy N, Ohnishi S, Nagai R, Kadowaki T (2009) Adiponectin suppresses hepatic SREBP1c expression in an AdipoR1/ LKB1/AMPK dependent pathway. Biochem Biophys Res Commun 382(1):51-56. doi:10.1016/j.bbrc.2009.02.131

Baarine M, Andreoletti P, Athias A, Nury T, Zarrouk A, Ragot K, Vejux A, Riedinger JM, Kattan Z, Bessede G, Trompier D, Savary S, Cherkaoui-Malki M, Lizard G (2012) Evidence of oxidative stress in very long chain fatty acid-treated oligodendrocytes and potentialization of ROS production using RNA interference-directed knockdown of ABCD1 and ACOX1 peroxisomal proteins. Neuroscience 213:1-18. doi:10.1016/j.neu roscience.2012.03.058

Bakan I, Laplante M (2012) Connecting mTORC1 signaling to SREBP-1 activation. Curr Opin Lipidol 23(3):226-234. doi:10. 1097/MOL.0b013e328352dd03

Barres R, Zierath JR (2011) DNA methylation in metabolic disorders. Am J Clin Nutr 93(4):897S-900S. doi:10.3945/ajen.110.001933

Bionaz M, Thering BJ, Loor JJ (2012) Fine metabolic regulation in ruminants via nutrient-gene interactions: saturated long-chain fatty acids increase expression of genes involved in lipid metabolism and immune response partly through PPAR-alpha activation. $\mathrm{Br}$ J Nutr 107(2):179-191. doi:10.1017/ S0007114511002777

Bligh EG, Dyer WJ (1959) A rapid method of total lipid extraction and purification. Can J Biochem Physiol 37(8):911-917

Bonefeld BE, Elfving B, Wegener G (2008) Reference genes for normalization: a study of rat brain tissue. Synapse 62(4):302-309. doi:10.1002/syn.20496
Buettner R, Parhofer KG, Woenckhaus M, Wrede CE, KunzSchughart LA, Scholmerich J, Bollheimer LC (2006) Defining high-fat-diet rat models: metabolic and molecular effects of different fat types. J Mol Endocrinol 36(3):485-501. doi:10. 1677/jme.1.01909

Burdge GC, Hanson MA, Slater-Jefferies JL, Lillycrop KA (2007) Epigenetic regulation of transcription: a mechanism for inducing variations in phenotype (fetal programming) by differences in nutrition during early life? Br J Nutr 97(6):1036-1046. doi:10. 1017/S0007114507682920

Cetin I, Alvino G, Cardellicchio M (2009) Long chain fatty acids and dietary fats in fetal nutrition. J Physiol 587(Pt 14):3441-3451. doi:10.1113/jphysiol.2009.173062

Cha JY, Repa JJ (2007) The liver X receptor (LXR) and hepatic lipogenesis. The carbohydrate-response element-binding protein is a target gene of LXR. J Biol Chem 282(1):743-751. doi:10. 1074/jbc.M605023200

Chen G, Liang G, Ou J, Goldstein JL, Brown MS (2004) Central role for liver X receptor in insulin-mediated activation of Srebp-1c transcription and stimulation of fatty acid synthesis in liver. Proc Natl Acad Sci USA 101(31):11245-11250. doi:10.1073/pnas. 0404297101

Church MW, Jen KL, Dowhan LM, Adams BR, Hotra JW (2008) Excess and deficient omega-3 fatty acid during pregnancy and lactation cause impaired neural transmission in rat pups. Neurotoxicol Teratol 30(2):107-117. doi:10.1016/j.ntt.2007.12. 008

Dasgupta S, Lonard DM, O’Malley BW (2014) Nuclear receptor coactivators: master regulators of human health and disease. Annu Rev Med 65:279-292. doi:10.1146/annurev-med-051812145316

de Assis AM, Rech A, Longoni A, Rotta LN, Denardin CC, Pasquali MA, Souza DO, Perry ML, Moreira JC (2012) Omega3Polyunsaturated fatty acids prevent lipoperoxidation, modulate antioxidant enzymes, and reduce lipid content but do not alter glycogen metabolism in the livers of diabetic rats fed on a high fat thermolyzed diet. Mol Cell Biochem 361(1-2):151-160. doi:10.1007/s11010-011-1099-4

de Oliveira Otto MC, Wu JH, Baylin A, Vaidya D, Rich SS, Tsai MY, Jacobs DR, Mozaffarian D (2013) Circulating and Dietary Omega-3 and Omega-6 Polyunsaturated Fatty Acids and Incidence of CVD in the Multi-Ethnic Study of Atherosclerosis. J Am Heart Assoc 2(6):e000506. doi:10.1161/JAHA.113.000506

Di Minno MN, Russolillo A, Lupoli R, Ambrosino P, Di Minno A, Tarantino G (2012) Omega-3 fatty acids for the treatment of non-alcoholic fatty liver disease. World J Gastroenterol 18(41):5839-5847. doi:10.3748/wjg.v18.i41.5839

Ding ST, McNeel RL, Mersmann HJ (2002) Modulation of adipocyte determination and differentiation-dependent factor 1 by selected polyunsaturated fatty acids. Vitro Cell Dev Biol Anim 38(6):352-357. doi:10.1290/1071-2690(2002)038<0352:MOA $\mathrm{DAD}>2.0 . \mathrm{CO} ; 2$

Fernandez-Alvarez A, Alvarez MS, Gonzalez R, Cucarella C, Muntane J, Casado M (2011) Human SREBP1c expression in liver is directly regulated by peroxisome proliferator-activated receptor alpha (PPARalpha). J Biol Chem 286(24): 21466-21477. doi:10.1074/jbc.M110.209973

Gillio-Meina C, Phang SH, Mather JP, Knight BS, Kennedy TG (2009) Expression patterns and role of prostaglandin-endoperoxide synthases, prostaglandin E synthases, prostacyclin synthase, prostacyclin receptor, peroxisome proliferator-activated receptor delta and retinoid $\mathrm{x}$ receptor alpha in rat endometrium during artificially-induced decidualization. Reproduction 137(3):537-552. doi:10.1530/REP-08-0294

Haggarty P (2010) Fatty acid supply to the human fetus. Annu Rev Nutr 30:237-255. doi:10.1146/annurev.nutr.012809.104742 
Haggarty P, Wood M, Ferguson E, Hoad G, Srikantharajah A, Milne E, Hamilton M, Bhattacharya S (2006) Fatty acid metabolism in human preimplantation embryos. Hum Reprod 21(3):766-773. doi:10.1093/humrep/dei385

Hansmannel F, Mordier S, Iynedjian PB (2006) Insulin induction of glucokinase and fatty acid synthase in hepatocytes: analysis of the roles of sterol-regulatory-element-binding protein-1c and liver X receptor. Biochem J 399(2):275-283. doi:10.1042/ BJ20060811

Harris WS (1989) Fish oils and plasma lipid and lipoprotein metabolism in humans: a critical review. J Lipid Res 30(6):785-807

Herrera E (2002) Implications of dietary fatty acids during pregnancy on placental, fetal and postnatal development-a review. Placenta 23(Suppl A):S9-S19. doi:10.1053/plac.2002.0771

Hirabara SM, Folador A, Fiamoncini J, Lambertucci RH, Rodrigues CF Jr, Rocha MS, Aikawa J, Yamazaki RK, Martins AR, Rodrigues AC, Carpinelli AR, Pithon-Curi TC, Fernandes LC, Gorjao R, Curi R (2013) Fish oil supplementation for two generations increases insulin sensitivity in rats. J Nutr Biochem 24(6):1136-1145. doi:10.1016/j.jnutbio.2012.08.014

Hogan JC, Stephens JM (2005) The regulation of fatty acid synthase by STAT5A. Diabetes 54(7):1968-1975

Holness MJ, Caton PW, Sugden MC (2010) Acute and long-term nutrient-led modifications of gene expression: potential role of SIRT1 as a central co-ordinator of short and longer-term programming of tissue function. Nutrition 26(5):491-501. doi:10.1016/j.nut.2009.09.012

Jump DB (2008) N-3 polyunsaturated fatty acid regulation of hepatic gene transcription. Curr Opin Lipidol 19(3):242-247. doi:10. 1097/MOL.0b013e3282ffaf6a

Jump DB, Botolin D, Wang Y, Xu J, Christian B, Demeure O (2005) Fatty acid regulation of hepatic gene transcription. J Nutr 135(11):2503-2506

Kagohashi Y, Abiru N, Kobayashi M, Hashimoto M, Shido O, Otani $\mathrm{H}$ (2010) Maternal dietary n-6/n-3 fatty acid ratio affects type 1 diabetes development in the offspring of non-obese diabetic mice. Congenit Anom (Kyoto) 50(4):212-220. doi:10.1111/j. 1741-4520.2010.00296.x

Kassam A, Capone JP, Rachubinski RA (2001) The short heterodimer partner receptor differentially modulates peroxisome proliferator-activated receptor alpha-mediated transcription from the peroxisome proliferator-response elements of the genes encoding the peroxisomal beta-oxidation enzymes acyl-CoA oxidase and hydratase-dehydrogenase. Mol Cell Endocrinol 176(1-2):49-56

Kris-Etherton PM, Taylor DS, Yu-Poth S, Huth P, Moriarty K, Fishell V, Hargrove RL, Zhao G, Etherton TD (2000) Polyunsaturated fatty acids in the food chain in the United States. Am J Clin Nutr 71(1 Suppl):179S-188S

Langley-Evans SC (2006) Developmental programming of health and disease. Proc Nutr Soc 65(1):97-105

Leal Soares L, Ferreira Medeiros de Franca Cardozo L, Andrade Troina A, De Fonte Ramos C, Guzman-Silva MA, Teles Boaventura G (2010) Influence of flaxseed during lactation on the reproductive system of female Wistar rats. Nutr Hosp 25(3):437-442. doi:10.1016/j.mrrev.2010.04.003

Lewis CA, Griffiths B, Santos CR, Pende M, Schulze A (2011) Regulation of the SREBP transcription factors by mTORC1. Biochem Soc Trans 39(2):495-499. doi:10.1042/BST0390495

Li S, Ogawa W, Emi A, Hayashi K, Senga Y, Nomura K, Hara K, Yu D, Kasuga M (2011) Role of S6K1 in regulation of SREBP1c expression in the liver. Biochem Biophys Res Commun 412(2):197-202. doi:10.1016/j.bbrc.2011.07.038

Liu HQ, Qiu Y, Mu Y, Zhang XJ, Liu L, Hou XH, Zhang L, Xu XN, Ji AL, Cao R, Yang RH, Wang F (2013) A high ratio of dietary n-3/n-6 polyunsaturated fatty acids improves obesity-linked inflammation and insulin resistance through suppressing activation of TLR4 in SD rats. Nutr Res 33(10):849-858. doi:10.1016/ j.nutres.2013.07.004

Makni M, Sefi M, el Garoui M, Fetoui H, Boudawara T, Zeghal N (2011) Dietary polyunsaturated fatty acid prevents hyperlipidemia and hepatic oxidant status in pregnant diabetic rats and their macrosomic offspring. J Diabetes Complicat 25(4):267-274. doi:10. 1016/j.jdiacomp.2011.02.002

Malik IA, Baumgartner BG, Naz N, Sheikh N, Moriconi F, Ramadori G (2010) Changes in gene expression of DOR and other thyroid hormone receptors in rat liver during acute-phase response. Cell Tissue Res 342(2):261-272. doi:10.1007/s00441-010-1067-4

Matorras R, Ruiz JI, Mendoza R, Ruiz N, Sanjurjo P, RodriguezEscudero FJ (1998) Fatty acid composition of fertilization-failed human oocytes. Hum Reprod 13(8):2227-2230

Mellouk Z, Hachimi Idrissi T, Louchami K, Hupkens E, Sener A, Yahia DA, Malaisse WJ (2012) The metabolic syndrome of fructose-fed rats: effects of long-chain polyunsaturated omega3 and omega6 fatty acids. II. Time course of changes in food intake, body weight, plasma glucose and insulin concentrations and insulin resistance. Int J Mol Med 29(1):113-118. doi:10. 3892/ijmm.2011.789

Moon YS, Latasa MJ, Griffin MJ, Sul HS (2002) Suppression of fatty acid synthase promoter by polyunsaturated fatty acids. J Lipid Res 43(5):691-698

Moon RJ, Harvey NC, Robinson SM, Ntani G, Davies JH, Inskip HM, Godfrey KM, Dennison EM, Calder PC, Cooper C (2013) Maternal plasma polyunsaturated fatty acid status in late pregnancy is associated with offspring body composition in childhood. J Clin Endocrinol Metab 98(1):299-307. doi:10.1210/jc.2012-2482

Nelissen K, Smeets K, Mulder M, Hendriks JJ, Ameloot M (2010) Selection of reference genes for gene expression studies in rat oligodendrocytes using quantitative real time PCR. J Neurosci Methods 187(1):78-83. doi:10.1016/j.jneumeth.2009.12.018

Newnham JP, Moss TJ, Nitsos I, Sloboda DM, Challis JR (2002) Nutrition and the early origins of adult disease. Asia Pac J Clin Nutr 11(Suppl 3):S537-S542

Niculescu MD, Lupu DS, Craciunescu CN (2013) Perinatal manipulation of alpha-linolenic acid intake induces epigenetic changes in maternal and offspring livers. FASEB J 27(1):350-358. doi:10.1096/fj.12-210724

Olefsky JM (2001) Nuclear receptor minireview series. J Biol Chem 276(40):36863-36864. doi:10.1074/jbc.R100047200

Pegorier JP, Le May C, Girard J (2004) Control of gene expression by fatty acids. J Nutr 134(9):2444S-2449S

Reeves PG, Nielsen FH, Fahey GC Jr (1993) AIN-93 purified diets for laboratory rodents: final report of the American Institute of Nutrition ad hoc writing committee on the reformulation of the AIN-76A rodent diet. J Nutr 123(11):1939-1951

Rice HB, Corwin RL (2002) Food intake in rats is unaffected by the profile of dietary essential fatty acids. Physiol Behav 75(5):611-619

Ronnebaum SM, Joseph JW, Ilkayeva O, Burgess SC, Lu D, Becker TC, Sherry AD, Newgard CB (2008) Chronic suppression of acetyl-CoA carboxylase 1 in beta-cells impairs insulin secretion via inhibition of glucose rather than lipid metabolism. J Biol Chem 283(21):14248-14256. doi:10.1074/jbc.M800119200

Sadana P, Zhang Y, Song S, Cook GA, Elam MB, Park EA (2007) Regulation of carnitine palmitoyltransferase I (CPT-Ialpha) gene expression by the peroxisome proliferator activated receptor gamma coactivator (PGC-1) isoforms. Mol Cell Endocrinol 267(1-2):6-16. doi:10.1016/j.mce.2006.11.012

Sealls W, Gonzalez M, Brosnan MJ, Black PN, DiRusso CC (2008) Dietary polyunsaturated fatty acids (C18:2 omega6 and C18:3 omega3) do not suppress hepatic lipogenesis. Biochim Biophys Acta 1781(8):406-414. doi:10.1016/j.bbalip.2008.06.010 
Sellmayer A, Danesch U, Weber PC (1996) Effects of different polyunsaturated fatty acids on growth-related early gene expression and cell growth. Lipids 31(Suppl):S37-S40

Simmons R (2011) Epigenetics and maternal nutrition: nature v. nurture. Proc Nutr Soc 70(1):73-81. doi:10.1017/ S0029665110003988

Simopoulos AP (2002) The importance of the ratio of omega-6/ omega-3 essential fatty acids. Biomed Pharmacother 56(8):365-379

Simopoulos AP, Leaf A, Salem N Jr (1999) Workshop on the essentiality of and recommended dietary intakes for omega- 6 and omega-3 fatty acids. J Am Coll Nutr 18(5):487-489

Somm E, Schwitzgebel VM, Toulotte A, Cederroth CR, Combescure C, Nef S, Aubert ML, Huppi PS (2009) Perinatal exposure to bisphenol a alters early adipogenesis in the rat. Environ Health Perspect 117(10):1549-1555. doi:10.1289/ehp.11342

Soulimane-Mokhtari NA, Guermouche B, Yessoufou A, Saker M, Moutairou K, Hichami A, Merzouk H, Khan NA (2005) Modulation of lipid metabolism by n-3 polyunsaturated fatty acids in gestational diabetic rats and their macrosomic offspring. Clin Sci (Lond) 109(3):287-295. doi:10.1042/CS20050028

Spiekerkoetter U, Wood PA (2010) Mitochondrial fatty acid oxidation disorders: pathophysiological studies in mouse models. J Inherit Metab Dis 33(5):539-546. doi:10.1007/s10545-0109121-7

Takashima M, Ogawa W, Emi A, Kasuga M (2009) Regulation of SREBP1c expression by mTOR signaling in hepatocytes. Kobe $\mathrm{J}$ Med Sci 55(2):E45-E52

Takeuchi Y, Yahagi N, Izumida Y, Nishi M, Kubota M, Teraoka Y, Yamamoto T, Matsuzaka T, Nakagawa Y, Sekiya M, Iizuka Y, Ohashi K, Osuga J, Gotoda T, Ishibashi S, Itaka K, Kataoka K, Nagai R, Yamada N, Kadowaki T, Shimano H (2010) Polyunsaturated fatty acids selectively suppress sterol regulatory element-binding protein-1 through proteolytic processing and autoloop regulatory circuit. J Biol Chem 285(15):11681-11691. doi:10.1074/jbc.M109.096107

Tapia G, Valenzuela R, Espinosa A, Romanque P, Dossi C, GonzalezManan D, Videla LA, D'Espessailles A (2014) N-3 long-chain PUFA supplementation prevents high fat diet induced mouse liver steatosis and inflammation in relation to PPAR-alpha upregulation and NF-kappaB DNA binding abrogation. Mol Nutr Food Res. doi:10.1002/mnfr.201300458

Teran-Garcia M, Adamson AW, Yu G, Rufo C, Suchankova G, Dreesen TD, Tekle M, Clarke SD, Gettys TW (2007) Polyunsaturated fatty acid suppression of fatty acid synthase (FASN): evidence for dietary modulation of NF-Y binding to the Fasn promoter by SREBP-1c. Biochem J 402(3):591-600. doi:10. 1042/BJ20061722

Tousoulis D, Plastiras A, Siasos G, Oikonomou E, Verveniotis A, Kokkou E, Maniatis K, Gouliopoulos N, Miliou A, Paraskevopoulos T, Stefanadis C (2014) Omega-3 PUFAs improved endothelial function and arterial stiffness with a parallel antiinflammatory effect in adults with metabolic syndrome. Atherosclerosis 232(1):10-16. doi:10.1016/j.atherosclerosis. 2013.10.014

Watson PJ, Fairall L, Schwabe JW (2012) Nuclear hormone receptor co-repressors: structure and function. Mol Cell Endocrinol 348(2):440-449. doi:10.1016/j.mce.2011.08.033

Yang ZH, Miyahara H, Takemura S, Hatanaka A (2011) Dietary saury oil reduces hyperglycemia and hyperlipidemia in diabetic KKAy mice and in diet-induced obese C57BL/6J mice by altering gene expression. Lipids 46(5):425-434. doi:10.1007/ s11745-011-3553-1

Yates CM, Calder PC, Ed Rainger G (2014) Pharmacology and therapeutics of omega- 3 polyunsaturated fatty acids in chronic inflammatory disease. Pharmacol Ther 141(3):272-282. doi:10. 1016/j.pharmthera.2013.10.010

Yecies JL, Zhang HH, Menon S, Liu S, Yecies D, Lipovsky AI, Gorgun C, Kwiatkowski DJ, Hotamisligil GS, Lee CH, Manning BD (2011) Akt stimulates hepatic SREBP1c and lipogenesis through parallel mTORC1-dependent and independent pathways. Cell Metab 14(1):21-32. doi:10.1016/j.cmet.2011.06.002

Yoshikawa T, Shimano H, Yahagi N, Ide T, Amemiya-Kudo M, Matsuzaka T, Nakakuki M, Tomita S, Okazaki H, Tamura Y, Iizuka Y, Ohashi K, Takahashi A, Sone H, Osuga Ji J, Gotoda T, Ishibashi S, Yamada N (2002) Polyunsaturated fatty acids suppress sterol regulatory element-binding protein $1 \mathrm{c}$ promoter activity by inhibition of liver X receptor (LXR) binding to LXR response elements. J Biol Chem 277(3):1705-1711. doi:10.1074/ jbc.M105711200

Yoshikawa T, Ide T, Shimano H, Yahagi N, Amemiya-Kudo M, Matsuzaka T, Yatoh S, Kitamine T, Okazaki H, Tamura Y, Sekiya M, Takahashi A, Hasty AH, Sato R, Sone H, Osuga J, Ishibashi S, Yamada N (2003) Cross-talk between peroxisome proliferator-activated receptor (PPAR) alpha and liver $\mathrm{X}$ receptor (LXR) in nutritional regulation of fatty acid metabolism. I. PPARs suppress sterol regulatory element binding protein-1c promoter through inhibition of LXR signaling. Mol Endocrinol 17(7):1240-1254. doi:10.1210/me.2002-0190

Zhang Y, Lei T, Huang JF, Wang SB, Zhou LL, Yang ZQ, Chen XD (2011) The link between fibroblast growth factor 21 and sterol regulatory element binding protein $1 \mathrm{c}$ during lipogenesis in hepatocytes. Mol Cell Endocrinol 342(1-2):41-47. doi:10.1016/ j.mce.2011.05.003

Zulkafli IS, Waddell BJ, Mark PJ (2013) Postnatal dietary omega-3 fatty acid supplementation rescues glucocorticoid-programmed adiposity, hypertension, and hyperlipidemia in male rat offspring raised on a high-fat diet. Endocrinology 154(9):3110-3117. doi:10.1210/en.2013-1153 